\title{
NK Cells in the Pathogenesis of Chronic Obstructive Pulmonary Disease
}

\author{
Yafei Rao, Yanqing Le, Jing Xiong, Yuqiang Pei and Yongchang Sun* \\ Department of Respiratory and Critical Care Medicine, Peking University Third Hospital, Beijing, China
}

Chronic obstructive pulmonary disease (COPD) is a prevalent chronic airway disease with varied frequencies of acute exacerbations, which are the main cause of morbidity and mortality of the disease. It is, therefore, urgent to develop novel therapies for COPD and its exacerbations, which rely heavily on understanding of the pathogenesis and investigation for potential targets. Current evidence indicates that natural killer (NK) cells play important roles in the pathological processes of COPD. Although novel data are revealing the significance of NK cells in maintaining immune system homeostasis and their involvement

OPEN ACCESS

Edited by:

Nicholas W. Lukacs, University of Michigan, United States

Reviewed by:

Christine Freeman, University of Michigan,

United States

Domenico Mavilio University of Milan, Italy

${ }^{*}$ Correspondence: Yongchang Sun suny@bjmu.edu.cn

Specialty section: This article was submitted to NK and Innate Lymphoid Cell Biology, a section of the journal

Frontiers in Immunology

Received: 09 February 2021 Accepted: 07 April 2021

Published: 04 May 2021

Citation:

Rao Y, Le Y, Xiong J, Pei Y and Sun Y (2021) NK Cells in the Pathogenesis of Chronic Obstructive Pulmonary Disease.

Front. Immunol. 12:666045. doi: 10.3389/fimmu.2021.666045 in pathogenesis of COPD, the specific mechanisms are largely unknown. Specific and indepth studies elucidating the underlying mechanisms are therefore needed. In this review, we provided a brief overview of the biology of NK cells, from its development to receptors and functions, and outlined their subsets in peripheral blood and lungs. Then we reviewed published findings highlighting the important roles played by NK cells in COPD and its exacerbations, with a view of providing the current state of knowledge in this area to facilitate related in-depth research.

Keywords: natural killer cells, chronic obstructive pulmonary disease, COPD, acute exacerbations, cigarette smoke, pathogenesis

\section{INTRODUCTION}

Chronic obstructive pulmonary disease (COPD) is a prevalent chronic airway disease with increasing morbidity and mortality globally (1-3). The global incidence of COPD was estimated to achieve $3.9 \%$, and caused a mortality of 41.9 per 100000 individuals in 2017 (2). A recent cross-sectional study in mainland China revealed an overall prevalence of $8.6 \%$ of spirometry-defined COPD in adult populations ( $\geq 20$ years old) (3). COPD is a preventable and treatable disease featured by persistent airway inflammation and parenchymal destruction, mostly caused by cigarette smoking. Clinically, COPD is usually manifested as exertional dyspnea, cough and/or sputum production $(4,5)$, and acute exacerbation of these symptoms, i.e., AECOPD, represents the main cause of COPD-related disabilities and mortality and accelerates disease progression $(6,7)$. Currently, main therapeutic interventions for COPD include non-pharmacological management (smoking cessation, influenza and pneumococcal vaccinations, rehabilitation), and pharmacological therapies with bronchodilators and/or inhaled corticosteroids. However, none of the available medications has been shown to modify disease progression and reduce mortality (5). It is, therefore, urgent to develop novel therapies for COPD and its exacerbations, which rely heavily on understanding of the pathogenesis and identification of potential targets. 
Studies have shown that immune-infiltrating cells play a pivotal role in the airway inflammation and lung destruction of COPD, including neutrophils, macrophages, lymphocyte subsets, and dendritic cells $(8,9)$. NK cells, as innate immune cells, are considered to be the first line of defense mechanism for the human body against infections and tumors (10). More recent evidence has implicated NK cells in maintaining immune homeostasis and in pathogenesis of COPD $(11,12)$. However, the specific mechanisms are still elusive $(13,14)$. Specific and indepth studies elucidating the underlying mechanisms are therefore needed. In this article, we provided an overview of the biology of NK cells, their subsets in peripheral blood and the lungs, and current knowledge on the potentially important roles played by NK cells in COPD and its exacerbations.

\section{HUMAN NK CELL DEVELOPMENT}

Over the past 40 years, great achievements have been made in the field of research on NK cells. Studies in humans revealed that the bone marrow (BM) and secondary lymphoid tissues (SLTs) such as tonsils, spleen, and lymph nodes (LNs) are essential organs for the differentiation and development of NK cells $(15,16)$. Different stages of this process were determined by unique surface biomarkers (15). During the initial phase, hematopoietic stem cells (HSCs) give rise to $\mathrm{CD} 34^{+} \mathrm{CD} 133^{+} \mathrm{CD} 38^{-} \mathrm{CD} 90^{-} \mathrm{CD} 45 \mathrm{RA}^{+}$ lymphoid-primed multipotential progenitor (LMPP) (17), and then, LMPP progress into common lymphoid progenitors (CLPs) with the expression of CD38, CD7, CD10, and CD127 (18-21). Hereafter, CD122 marks the irreversible transition of CLPs into NK lineage, and then develop into its mature form via CD56 expression (22). Some works have also categorized the development of NK cells into six stages according to the studies pertaining to BM and LNs development $(15,16)$. $\mathrm{CD} 3 \epsilon^{-} \mathrm{CD} 7^{+} \mathrm{CD} 127^{+}$cell subgroup defines the transformation of NK cells from stage 1 through stage $2 \mathrm{a}$. Expression of IL-1R marks the initiation of stage $2 \mathrm{~b}$. Then NK cells come to stage 3 with the expression of activating receptors involving NK cell group 2D(NKG2D), CD335 and CD337. During stage 4, NK cell development is comprised of two sections: stage 4a and stage $4 \mathrm{~b}$. NK cells in Stage 4a are NKP80- that have high expression of NKG2D, CD335, CD337, inhibitory NKG2A and CD161. Besides, this stage also exhibits high expression of CD56 $\left(\mathrm{CD} 56^{\text {bright }}\right)$. On the other hand, NK cells in stage $4 \mathrm{~b}$ are $\mathrm{NKP}^{+} 0^{+}$while sustain CD56 ${ }^{\text {bright }}$ status $(23,24)$. Stage 5 of development is denoted by a proportion of NK cells with downregulated CD56 (CD56 ${ }^{\mathrm{dim}}$ ) and upregulated CD16 (25). Finally, stage 6 of the development, also known as terminal maturation, occurs following expression of CD57 (26).

\section{SUBGROUPS OF HUMAN NK CELLS IN PERIPHERAL BLOOD AND LUNGS}

$\mathrm{NK}$ cells are defined as $\mathrm{CD}^{-} \mathrm{CD}^{+} 6^{+}$cells, which make up approximately $5-15 \%$ of the circulating lymphocytes. NK cells are subdivided into two main subpopulations, CD56 ${ }^{\text {bright }} \mathrm{CD} 16$ and $\mathrm{CD} 56^{\mathrm{dim}} \mathrm{CD} 16^{+}$, based on expression of the surface marker CD56 and CD16. CD56 ${ }^{\text {bright }}$ CD16 ${ }^{-} \mathrm{NK}$ cells, accounting for about $10 \%$ of peripheral blood (PB) NK population, mainly produce cytokines, including interferon-gamma (IFN- $\gamma$ ), interleukin (IL)10 , tumor necrosis factor- $\alpha$ (TNF- $\alpha$ ), granulocyte-macrophage colony-stimulating factor. CD56 ${ }^{\mathrm{dim}} \mathrm{CD} 16^{+} \mathrm{NK}$ cells are the predominant $(90 \%)$ peripheral blood (PB) NK population, which are highly cytotoxic by producing a large amount of perforin and granzymes, expressing Ig-like receptors (KIRs), and inducing antibody-dependent cytotoxicity (ADCC) effects, but with limited ability to produce cytokines (27-29).

In recent years, emerging evidence indicates that $\mathrm{NK}$ cells also reside in peripheral tissues including liver, lung, spleen, BM, intestine and uterus under steady-state conditions (Figure 1). Studies indicated that the majority of NK cells in the lung, BM, LNs and spleen are CD56 ${ }^{\mathrm{dim}} \mathrm{CD} 16^{+}$, while CD $56^{\text {bright }} \mathrm{CD} 16^{-} \mathrm{NK}$ cells predominate in the liver, gut and uterus (30-34). NK cells in the spleen, BM and LNs comprise $5-20 \%, 4 \%$ and $2-5 \%$ of the total lymphocyte population, respectively. $\mathrm{CD} 56{ }^{\text {bright }} \mathrm{CD} 69^{+}$ $\mathrm{CXCR}^{+}{ }^{+} \mathrm{NK}$ cells define the BM and spleen resident NK cells, which make up a proportion of $9-51 \%$ in BM NK cells, and $28-69 \%$ in spleen NK cells, respectively. While CD56 ${ }^{\mathrm{dim}}$ $\mathrm{CXCR}^{+} \mathrm{CD} 9^{+} \mathrm{NKP}^{+} 6^{+} \mathrm{NK}$ cells define $\mathrm{LN}$ resident $\mathrm{NK}$ cells, accounting for $43-67 \%$ of the LN NK cells $(34,35)$. Dogra et al. found that the frequencies of NK cells in BM, spleen and lung were higher than those in LNs and gut, and interestingly, they also demonstrated that tissue sites shaped the functions of NK cells, especially the potential for cytokine production (31). In humans, NK cells constitute approximately 5-20\% of the CD45positive lung lymphocytes, and are located in lung parenchyma (28). Most lung NK cells show a mature CD56 ${ }^{\mathrm{dim}} \mathrm{CD} 16^{+}$ phenotype which takes a proportion of $80 \%$ (29), whereas CD56 ${ }^{\text {bright }} \mathrm{CD} 16^{-}$and $\mathrm{CD} 56^{\mathrm{dim}} \mathrm{CD} 16^{-}$cells make up the remaining $20 \%$, in equal ratios $(12,36)$. However, it should be noted that the majority of lung NK cells are circulating cells, though hypofunctional, otherwise are similar to PB NK cells. A minority of the lung NK cells are tissue-resident, and could be specifically defined by $\mathrm{CD} 49 \mathrm{a}^{+} \mathrm{CD} 69^{+} \mathrm{CD} 103^{+}$cells, which constitute $20 \%$ of lung NK cells (34). Due to the difficulty of obtaining human lung NK cell samples, the research in human lung NK cells is very limited. Thus, further investigations are needed to fill the gap in understanding of human lung NK cells in pulmonary diseases.

\section{HUMAN NK CELL RECEPTORS AND THEIR FUNCTIONS}

Human NK cells express a variety of receptors, including inhibitory, activating, cytokine, chemokine receptors and death receptors (Figure 2). Inhibitory receptors are expressed when immune surveillance is normal, among them are killer KIRs such as KIR2DL1, KIR2DL2/3, KIR3DL1, KIR3DL2, KIR2DL5 (expressed by subsets of CD56 ${ }^{\mathrm{dim}} \mathrm{NK}$ cells) and KIR2DL4 (expressed by all mature CD56 ${ }^{\mathrm{dim}} \mathrm{NK}$ cells), CD94: NKG2A heterodimers and immunoglobulin-like transcript 2(ILT-2). 


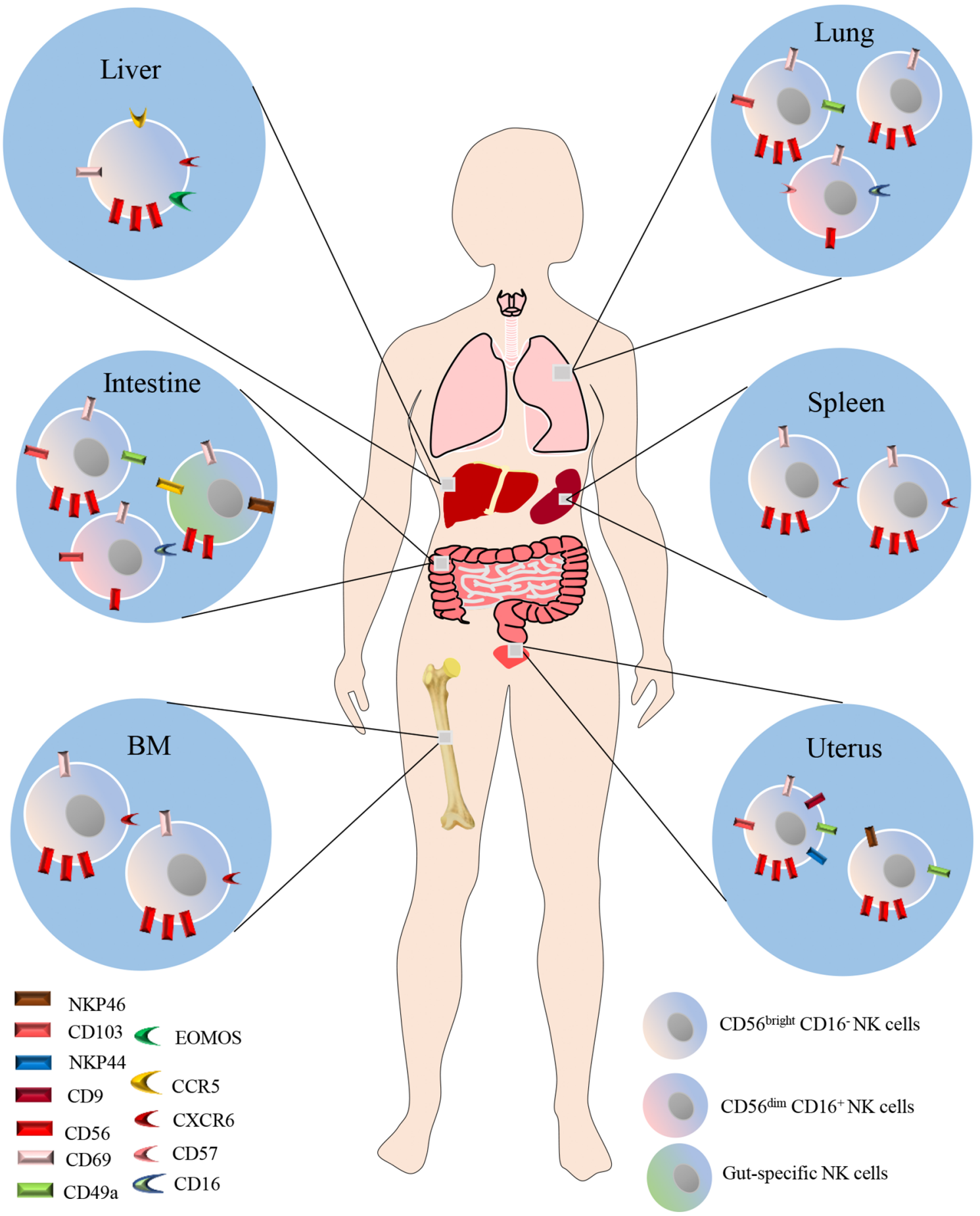

FIGURE 1 | NK cells also reside in peripheral tissues including liver, lung, spleen, BM, intestine and uterus under steady-state conditions. The majority of NK cells in the lung, BM, LNs and spleen are CD56 ${ }^{\text {dim }} \mathrm{CD} 16^{+}$, while CD56 ${ }^{\text {bright }} \mathrm{CD} 16^{-} \mathrm{NK}$ cells predominate in the liver, gut and uterus. CD56 ${ }^{\text {bright }} \mathrm{CD} 69^{+}$CXCR6 ${ }^{+}$NK cells define the BM and spleen resident NK cells. While CD56 ${ }^{\text {dim } C X C R 6}{ }^{+} \mathrm{CD} 69^{+} \mathrm{NKP} 466^{+} \mathrm{NK}$ cells define LN resident NK cells. In humans, NK cells constitute approximately $5-20 \%$ of the CD45-positive lung lymphocytes, and are located in lung parenchyma. Most lung NK cells show a mature CD56 ${ }^{\text {dim }}$ CD16 ${ }^{+}$phenotype which takes a proportion of $80 \%$, whereas CD56 ${ }^{\text {bright }} \mathrm{CD} 16^{-}$and $\mathrm{CD} 56^{\mathrm{dim}} \mathrm{CD} 16^{-}$cells make up the remaining $20 \%$, in equal ratios. A minority of the lung NK cells are tissue-resident, and could be specifically defined by CD49a ${ }^{+} \mathrm{CD}_{69}{ }^{+} \mathrm{CD} 103^{+}$cells, which constitute $20 \%$ of lung NK cells. 
A

NKG2C/KLRD-1

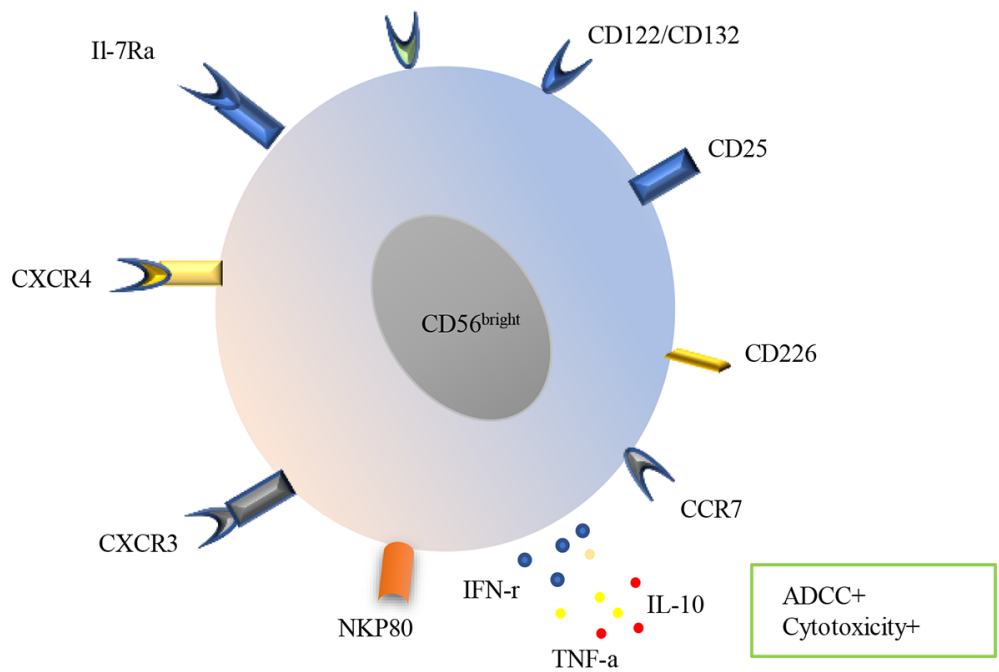

B

NKG2C/KLRD-1

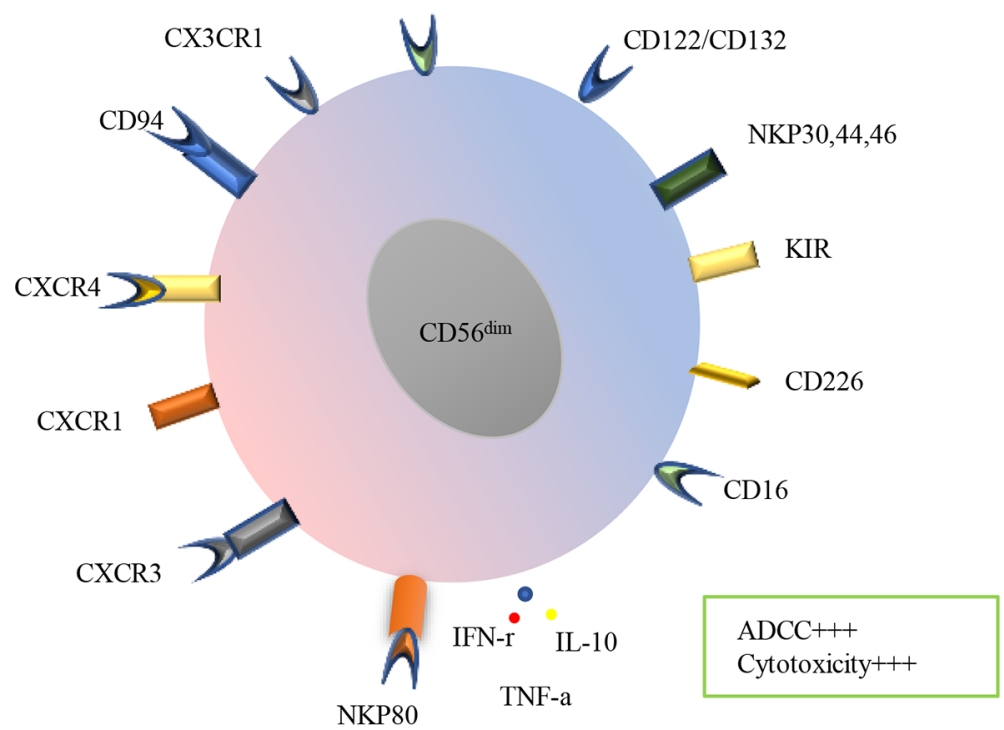

FIGURE 2 | Surface receptors and functions of PB human NK cells subtypes. Human NK cells are divided into CD56 bright $($ A) and CD56 dim (B) subsets in PB, which express a variety of receptors, including inhibitory, activating, cytokine, chemokine receptors and death receptors. CD56 bright subset mainly expresses CCR7, CD226, CD25, CD122/132, NKG2C/KLRD-1, IL-7Ra CXCR4, CXCR3and NKP80, meanwhile, CD56 dim subset mainly expresses CD16, CD226, KIR, NKP30, NKP44, NKP46, CD122/CD132, NKG2C/KLRD-1, CX3CR1 CD94, CXCR4, CXCR1, CXCR3. CD56 bright subset produces more IFN- $\gamma$, TNF- $\alpha$ and IL-10 while less ADCC and cytotoxicity. In contrast, CD56 ${ }^{\text {dim }}$ subset produces less cytokines, however prominent ADCC and cytotoxicity.

Recently, several other inhibitory receptors have also been reported, including programmed cell death protein 1 (PD-1), $\mathrm{T}$ cell immunoglobulin and immunoreceptor tyrosine-based inhibitory motif domain (TIGIT), cytotoxic T lymphocyte antigen-4 (CTLA-4), lymphocyte-activation gene 3 (LAG-3), killer cell lectin-like receptor subfamily G member 1 (KLRG1), CD161, T cell immunoglobulin domain and mucin domain-3 (TIM-3) (37). All mature NK cells may also express the inhibitory receptor IRp60 and p75/AIRMI. Inhibitory receptors mainly recognize classical and non-classical major histocompatibility complex (MHC) class I molecules $(38,39)$. Regulation of the balance between inhibitory and activating receptors determines NK cell effects. NK cells are activated by tumor or infected cells lacking inhibitory receptor ligands or having abundant activating receptor ligands. NK cells will undergo activation if the activating signals surpasses the MHC class I inhibitory receptors (40-42). Activating receptors include natural cytotoxicity receptors (NKp30, NKp44, and NKp46), natural killer group 2C (NKG2C), NKG2D, CD16, KIR2DS1, KIR2DS2/3, KIR2DL4, KIR3DS1, KIR2DS5, KIR2DS4, NKRP-1, 
CD226 as well as coreceptors (2B4, NTB-A, and NKp80) (10, 38, 39). NK cells may also express many other cytokine and chemokine receptors, including IL-2Ra, IL-2Rb/IL-2Rc, c-Kit, IL-7Ra, CXCR1, CXCR3, CXCR4, CCR4, CCR7, IL-18R, ChemR23 and CX3CR1. In addition, death receptors such as TNF-related apoptosis-inducing ligand (TRAIL), Fas and Apol as well as ligands including Fas ligand and CD40L have also been reported in NK cells (39). Knowledge of these receptors and their functions is essential for understanding the role of NK cells in diseases including COPD.

\section{NK CELLS IN VIRAL AND BACTERIAL LUNG INFECTIONS}

NK cells play a vital role in lung immune response to respiratory viral and bacterial infections. During the early phase of influenza infection in mice, NK cells accumulate in the lung to clear the virus via IFN- $\gamma$ production, adaptive immune cell activation, ADCC and direct lysis $(43,44)$. Studies have demonstrated that patients with genetic deficiency with loss of NK cell function suffered from recurrent viral infection (45-47). However, NK cells may not always protective. Deletion of NK cells promote the survival of mice infected with highdose influenza viruses via mitigating lung immunopathology, suggesting the destructive role of NK cells in influenza infection. It seems likely that NK cells play a dual role in influenza infection.

Recent evidence indicates that NK cells may play an increasingly vital role in bacterial infections. During infection with Mycobacterium tuberculosis, NK cells upregulated CD69, IFN- $\gamma$ and perforin expression for promotion of host defense against the bacteria. However, it is still unclear whether NK cells employ cytotoxic lysis to restrict Mycobacterium tuberculosis, and therefore further investigations are needed (48-51). In another study, lung NK cells protect the host against $K$. pneumoniae infection via IL-22 and IFN- $\gamma$ production. Similarly, lung NK cells defend against Pseudomonas aeruginosa infection via NKG2D expression and IFN- $\boldsymbol{\gamma}$ production $(52,53)$. Yoshihara et al. found that NK cells facilitate host defense against Staphylococcus aureus infection through IFN- $\gamma$ and TNF production $(54,55)$. Similarly, lung NK cells could also protect against Haemophilus influenzae through IFN- $\gamma$ production. Overall, current knowledge shows that NK cells play a beneficial role in the restriction of bacterial infection (56).

\section{NK CELLS IN ANIMAL MODELS OF COPD Frequency of NK Cells in COPD}

An earlier study by Motz et al. found no significant change of lung NK cells after 6-month cigarette smoke (CS) exposure in a mouse model of COPD (57). Similar results were confirmed by Wortham et al. who observed no difference in the number of lung NK cells between 6-month CS-exposed and air-exposed mice (58). Additionally, another study reported that short-term CS exposure (4 days) did not increase the frequency of NK cells in the lung (59). On the contrary, Stolberg et al. found that lung
NK cells showed elevated frequency after 4-day CS exposure (60). The reasons for conflicting results from these studies are not clear, but may be explained by differences in experimental protocols, CS exposure times and doses.

\section{Activating Receptors of NK Cells in COPD}

The study by Wortham et al. found that the activating receptors of NK1.1, NKG2D, and CD244 in lung and spleen NK cells did not differ between 6-month CS-exposed and air-exposed mice (61). In contrast, Stolberg et al. found that after a short-term of 4day CS exposure, lung NK cells showed elevated CD69 expression, which could be mitigated by CCR4 deletion. Additionally, they found that short-term CS exposure could significantly induce the expression of retinoic acid early transcript 1 protein (RAET1) (NKG2D ligand) in lung airway epithelium (60). Other studies also confirmed that long-term CS exposure could significantly induce the expression of NKG2D ligand expression including RAET1 and Mult1, which were shown to contribute to pulmonary emphysema $(58,62)$. Similarly, in a spontaneous COPD mouse model, Finch et al. observed increased percentage of $\mathrm{CD}^{+} 9^{+}$lung NK cells (14). These discrepancies in activating receptors of NK cells in COPD models maybe explained by differences in CS exposure times and doses, the receptors studies, and the compartments of NK cells. Collectively, these data indicate that activating receptors of NK cells are altered and may play an important role in lung inflammation and emphysema of COPD.

\section{Inhibitory Receptors of NK Cells in COPD}

Thus far, there has been limited data on the inhibitory receptors of NK cells in COPD models. In the study by Wortham et al., the inhibitory receptor CD94 as heterodimerized with NKG2A/C subunits in the lung and spleen showed no difference between 6 month CS-exposed and air-exposed mice (58). Indeed, further experimental evidence is needed to elucidate the potential role of NK cell inhibitory receptors in the pathological mechanisms of COPD.

\section{Altered Effector Functions of NK Cells in COPD}

The study by Wortham and his colleagues found that NK cells from 6-month CS-exposed mice showed elevated cytotoxicity toward NKG2D ligand RAET1€ (58). Similarly, Motz et al. found that lung and spleen NK cells from 8-week CS-exposed mice demonstrated elevated cytotoxicity following Ly49D or NK1.1 challenge. In this study, they also found that lung and spleen NK cells in CS-exposed mice showed higher IFN-rproduction following IFN- $\gamma$-inducing cytokine challenge including IL-12 or IL-18, or both. Particularly, they found that IFN- $\gamma^{+}$NK cells decreased significantly after IL-12 treatment following smoking cessation (57). In another study, Finch et al. observed that lung NK cells from 8-week CS exposed mice showed elevated cytotoxicity toward lung epithelial cells in relative to control group. In this article, they also found that DCs were necessary for the priming of $\mathrm{NK}$ cells to acquire cytotoxicity potential following CS exposure, which could be abrogated by blocking IL-15 (14). Additionally, another study demonstrated that CS 
could prime NK cells for the production of IL-17A (59). Stolberg et al. found that lung NK cells from mice exposed to CS for 4

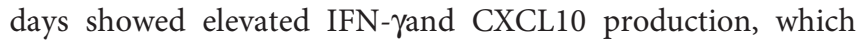
could be abrogated by CCR4 deletion. Also, they found that CCR4 was required for $\mathrm{NK}$ cells' contacting with lung

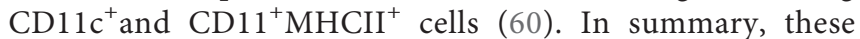
studies imply that the CS exposure may exaggerate lung epithelial cell injury through increased NK cell cytotoxicity and cytokine production.

\section{NK Cells in AECOPD of Mice}

Other studies demonstrated that NK cells produced much more IFN- $\gamma$ in CS-induced COPD models after viral infection or after viral pathogen-associated molecular patterns (PAMPs) challenge (63). Additionally, IFN- $\gamma^{+}$lung NK cells frequency from in CS exposed mice for 8 weeks responded differently to different bacterial PAMPs: increase for LPS, no difference for HKLM and ST-FLA, decrease for pam3CSK4 (57). Another study found that infection of mice with virus in six-month CS exposure showed exaggerated inflammation and airway epithelial damage. However, this augmented damage could be mitigated in NKG2D deletion mice, indicating the pivotal role of NKG2D in viral infection induced COPD exacerbations (58). In contrast, one study by Mian et al. showed that CS inhibited IL-15 mediated NK cells activation, manifested as decreased CD69, NKG2D and Granzyme B expression as well as NK cell cytotoxicity following poly I:C stimulation (64). In line with this, Pichavant et al. found that the NK cells in 12-week CS-exposed mice showed defective immune response upon $S$. pneumoniae challenge (65). In all, the study of NK cells in AECOPD of mice is still in its infancy, there is an urgent need to assess the role of NK cells in AECOPD with more innovative approaches.

\section{NK CELLS IN HUMAN COPD}

Evidence indicates that immune-infiltrating cells play a pivotal role in the pathogenesis of $\operatorname{COPD}(8,9)$. NK cells act as a proinflammatory population during the immune response (12). Theoretically, NK cells could cause the injury to the lung, and thus COPD pathogenesis. However, their precise role in the pathogenesis of COPD remained elusive with discrepant studies in humans (Table 1). Alterations of NK cells, as manifested by surface marker including inhibitory receptors, activating receptors (Table 2), as well as effector functions occur in stable COPD patients and smokers.

\section{Frequency of NK Cells}

As the disease progresses, the frequency of NK cells may also change. One study by Richard et al. indicated that the percentage of induced sputum NK cells increased significantly in COPD patients compared with healthy non-smokers (HNS) and smokers. CD56 ${ }^{\text {bright }} \mathrm{CD} 16^{-}$induced sputum NK cells subset also increased significantly in COPD patients in relative to the two other groups (74). Another study observed an elevated percentage of PB NK cells in COPD patients compared with HNS (69). Similarly, Chen et al. also observed an elevated percentage of PB NK cells in cigarette smoking-related COPD patients (67). In addition, another study by Olloquequi et al. showed increased NK cells in lung lymphoid follicles (75). However, NK cells may not always increase. Several studies gave opposite results showing decreased frequencies of $\mathrm{PB}$ $\mathrm{CD}_{16}{ }^{+} \mathrm{NK}$ cells in smokers as compared to nonsmokers, which persisted years after ceasing smoking $(76,77)$. Similarly, one study demonstrated that the percentage of NK cells decreased significantly in COPD patients compared with HNS. The $\mathrm{CD} 56^{\mathrm{dim}} \mathrm{CD} 16^{+} \mathrm{PB}$ NK cells subset also reduced in COPD patients in relative to smokers and HNS with a corresponding elevation of the $\mathrm{CD} 56^{\text {bright }} \mathrm{CD} 16^{-}$cells (78). Interestingly, Pascual et al. pointed out that $\mathrm{PB}$ NK cell frequency showed no difference between HNS and COPD patients disregarding disease severity (68). Hodge et al. confirmed that there were no changes in the percentage of $\mathrm{PB}$ NK cells between HNS, smokers, current smoker COPD and ex-smoker COPD. However, this study observed an elevated frequency of bronchoalveolar lavage fluid (BALF) NK cells in COPD patients compared with HNS (13). Taken together, currently available data indicate that the NK cell population increases in the pulmonary compartment of COPD, but varies in the blood circulation.

\section{Activating Receptors of NK Cells}

There are a variety of activating receptors on the surface of NK cells, which are crucial for the function of NK cells (39). Wang et al. observed elevated frequency of activated $\left(\mathrm{CD} 69^{+} \mathrm{CD} 25^{-}\right.$; $\mathrm{CD} 9^{+} \mathrm{CD} 25^{+}$; $\mathrm{CD} 9^{-} \mathrm{CD} 25^{+}$) NK cells in $\mathrm{PB}$ of healthy smokers, current smokers and ex-smokers with COPD in relative to healthy non-smokers, and this was positively correlated with the number of cigarettes smoked. Additionally, they found increased proportion of activated induced sputum NK cells in current smokers with COPD and ex-smokers with COPD compared with healthy non-smokers. Interestingly, the proportion of activated NK cells was elevated in current smokers with COPD compared healthy smokers. These data implied that activating receptors in NK cells were close related with COPD state and cigarettes smoked. However, no differences were observed in NKG2D expression between groups (66). More recently, it was demonstrated that there were no differences in the percentage of $\mathrm{NKG}_{2} \mathrm{C}^{+} \mathrm{PB} \mathrm{NK}$ cells between COPD patients and HNS, and no correlation was observed with disease severity, smoking status. However, they found decreased $\mathrm{NKG}_{2} \mathrm{~A}^{+} \mathrm{NK}$ cells in COPD patients in relative to HNS. Yet, $\mathrm{NKG}_{2} \mathrm{~A}^{+} \mathrm{PB} \mathrm{NK}$ cells level were in no correlation with disease severity, smoking status and exacerbations frequency (68). Additionally, Hodge et al. and his colleagues reported that there were no changes in the percentage of $\mathrm{CD} 9^{+} \mathrm{PB} \mathrm{NK}$ cells between COPD patients and HNS groups (13). Overall, these studies gave absolute different observation, thus a profiling of NK cells receptors are urgently needed.

\section{Inhibitory Receptors of NK Cells}

Studies have found a variety of crucial inhibitory receptors in the surface of NK cells which are crucial for NK cells function (39) One study by Wang et al. demonstrated that the proportion of PB NK cells expressing CD158e1 was significantly decreased in healthy smokers and current smokers with COPD in relative to HNS (66). In line with this, Hodge et al. found that both PB and 
TABLE 1 | Studies of human NK cells in COPD.

\begin{tabular}{|c|c|c|c|c|c|}
\hline References & Patients & Compartment & $\begin{array}{l}\text { Functional } \\
\text { assay }\end{array}$ & Observations in NK cells & Key findings \\
\hline $\begin{array}{l}\text { Wang et al. } \\
(66)\end{array}$ & $\begin{array}{l}\text { HNS } 21 \\
\text { Smokers } 21 \\
\text { CuS-COPD } 14 \\
\text { ExS-COPD } 10\end{array}$ & PB & Yes & $\begin{array}{l}\text { Decreased CD158e1 expression in smokers and CUS-COPD } \\
\text { compared with HNS }\end{array}$ & $\begin{array}{l}\text { Hyperfunction of NK } \\
\text { cells in COPD }\end{array}$ \\
\hline $\begin{array}{l}\text { Chen et al. } \\
(67)\end{array}$ & $\begin{array}{l}\text { HNS } 16 \\
\text { COPD } 40\end{array}$ & $\mathrm{~PB}$ & Yes & Increased NK cells in COPD, decreased FPR3 expression & $\begin{array}{l}\text { Immune imbalance in } \\
\text { COPD }\end{array}$ \\
\hline $\begin{array}{l}\text { Pascual et al. } \\
\text { (68) }\end{array}$ & $\begin{array}{l}\text { HNS } 13 \\
\text { COPD } 66\end{array}$ & PB & No & $\begin{array}{l}\text { Increased NK cells in severe-to-very severe COPD VS mild- } \\
\text { moderate COPD }\end{array}$ & $\begin{array}{l}\text { Immune imbalance in } \\
\text { COPD }\end{array}$ \\
\hline $\begin{array}{l}\text { Hodge et al. } \\
\text { (13) }\end{array}$ & $\begin{array}{l}\text { HNS } 25 \\
\text { Smokers } 16 \\
\text { CuS-COPD } 30 \\
\text { ExS -COPD } 41\end{array}$ & PB & Yes & $\begin{array}{l}\text { Increased CD94 and Granzyme B expression in COPD compared } \\
\text { with HNS; no difference of CD69 between COPD and HNS group }\end{array}$ & $\begin{array}{l}\text { Hyperfunction of NK } \\
\text { cells in COPD }\end{array}$ \\
\hline Fang et al. (69) & $\begin{array}{l}\text { HNS } 12 \\
\text { COPD } 19\end{array}$ & PB & Yes & Elevated NK cells in COPD patients, decreased IFN- $\gamma$ production & $\begin{array}{l}\text { Hypofunction of NK } \\
\text { cells in COPD }\end{array}$ \\
\hline $\begin{array}{l}\text { Finch et al. } \\
(14)\end{array}$ & $\begin{array}{l}\text { ExS } 4 \\
\text { CuS } 15 \\
\text { CuS-COPD } 14 \\
\text { ExS -COPD } 16\end{array}$ & Lung & Yes & Increased NK cells cytotoxicity in COPD compared with HNS & $\begin{array}{l}\text { Hyperfunction of NK } \\
\text { cells in COPD }\end{array}$ \\
\hline $\begin{array}{l}\text { Wang et al. } \\
(66)\end{array}$ & $\begin{array}{l}\text { HNS } 5 \\
\text { Smokers } 10 \\
\text { CuS-COPD } 5 \\
\text { ExS -COPD } 6\end{array}$ & $\begin{array}{l}\text { Induced } \\
\text { sputum }\end{array}$ & Yes & $\begin{array}{l}\text { Increased } \mathrm{CD} 69^{+} \text {and/or } \mathrm{CD} 25^{+} \mathrm{NK} \text { cells in CuS-COPD and ExS } \\
\text {-COPD patients compared with HNS }\end{array}$ & $\begin{array}{l}\text { Hyperfunction of NK } \\
\text { cells in COPD }\end{array}$ \\
\hline $\begin{array}{l}\text { Hodge et al. } \\
\text { (13) }\end{array}$ & $\begin{array}{l}\text { HNS } 19 \\
\text { Smokers } 12 \\
\text { COPD } 33\end{array}$ & BALF & Yes & $\begin{array}{l}\text { Increased NK cells frequency, cytotoxicity, Granzyme B, CD94 in } \\
\text { COPD patients compared with HNS and smokers }\end{array}$ & $\begin{array}{l}\text { Hyperfunction of NK } \\
\text { cells in COPD }\end{array}$ \\
\hline $\begin{array}{l}\text { Prieto et al. } \\
(70)\end{array}$ & $\begin{array}{l}\text { HNS } 50 \\
\text { COPD } 60\end{array}$ & PB & Yes & Decreased cytotoxicity in COPD patients & $\begin{array}{l}\text { Hypofunction of NK } \\
\text { cells in COPD }\end{array}$ \\
\hline $\begin{array}{l}\text { Hughes et al. } \\
(71)\end{array}$ & $\begin{array}{l}\text { HNS } 32 \\
\text { Smokers } 14\end{array}$ & PB & Yes & Decreased cytotoxicity in heavy smokers, but normal ADCC & $\begin{array}{l}\text { Hypofunction of NK } \\
\text { cells in COPD }\end{array}$ \\
\hline $\begin{array}{l}\text { Phillips et al. } \\
\text { (72) }\end{array}$ & $\begin{array}{l}\text { HNS } 22 \text { Light/moderate } \\
\text { smokers } 12 \\
\text { Heavy smokers } 12\end{array}$ & PB & Yes & Declined cytotoxicity in heavy smokers, normal in mild smokers & $\begin{array}{l}\text { Hypofunction of NK } \\
\text { cells in COPD }\end{array}$ \\
\hline $\begin{array}{l}\text { Freeman et al. } \\
\text { (73) }\end{array}$ & $\begin{array}{l}\text { Smokers } 6 \\
\text { Mild COPD } 14 \\
\text { Severe COPD } 15\end{array}$ & lung & Yes & Elevated cytotoxicity in COPD & $\begin{array}{l}\text { Hyperfunction of NK } \\
\text { cells in COPD }\end{array}$ \\
\hline $\begin{array}{l}\text { Urbanowicz } \\
\text { et al. (16) }\end{array}$ & $\begin{array}{l}\text { HNS } 5 \\
\text { Smokers } 10 \\
\text { COPD } 11\end{array}$ & $\begin{array}{l}\text { Induced } \\
\text { sputum }\end{array}$ & Yes & $\begin{array}{l}\text { Elevated frequency and higher perforin and granzyme B } \\
\text { production in CD56 } 6^{\text {bright }} \text { CD16 } 6^{-} \text {subset of COPD patients } \\
\text { compared with HNS and smokers. }\end{array}$ & $\begin{array}{l}\text { Hyperfunction of NK } \\
\text { cells in COPD }\end{array}$ \\
\hline
\end{tabular}

TABLE 2 | Activating and inhibitory receptors in COPD of human.

\begin{tabular}{|c|c|c|c|c|}
\hline Receptor type & Name & Compartment & Findings & Reference \\
\hline \multirow[t]{4}{*}{$\begin{array}{l}\text { Activating } \\
\text { receptors }\end{array}$} & $\begin{array}{l}\text { CD69 and or } \\
\text { CD25 }\end{array}$ & $\begin{array}{l}\text { PB/Induced } \\
\text { sputum }\end{array}$ & Increased CD69 ${ }^{+}$and/or CD25 ${ }^{+}$in smokers CuS-COPD and ExS-COPD compared with HNS & $(66)$ \\
\hline & NKG2C & PB & $\begin{array}{l}\text { Elevated frequency NKG2C }{ }^{+} \mathrm{NK} \text { cells in frequently exacerbation COPD compared with occasional } \\
\text { exacerbated COPD }\end{array}$ & $(70)$ \\
\hline & NKG2C/NKG2A & $\mathrm{PB}$ & $\begin{array}{l}\text { No difference of NKG2C }{ }^{+} \text {NK cells between COPD and HNS, decreased NKG2A }{ }^{+} \text {in COPD } \\
\text { compared with HNS }\end{array}$ & $(68)$ \\
\hline & CD69 & PB & No changes of $\mathrm{CD} 69^{+} \mathrm{NK}$ cells between COPD and HNS & $(13)$ \\
\hline \multirow{4}{*}{$\begin{array}{l}\text { Inhibitory } \\
\text { receptors }\end{array}$} & CD158e1 & $\mathrm{PB}$ & Decreased CD158e $1^{+} \mathrm{NK}$ cells in smokers and CuS-COPD compared with HNS & $(66)$ \\
\hline & CD94 & PB & Decreased $\mathrm{CD}_{4} 4^{+} \mathrm{NK}$ cells in CuS-COPD compared with HNS & (13) \\
\hline & CD94 & BALF & No difference between smokers and HNS, decrease in CuS-COPD compared with HNS & (13) \\
\hline & $\begin{array}{l}\text { CD158a/ } \\
\text { CD158b }\end{array}$ & PB & Decreased CD158a ${ }^{+}$and CD158b ${ }^{+}$in COPD compared with HNS & (69) \\
\hline
\end{tabular}

BALF NK cells' inhibitory receptor CD94 was also significantly decreased in current smoker COPD patients compared with HNS. However, there was no alteration of PB NK cells CD94 in healthy smokers compared with HNS. Meanwhile, no difference was observed in BALF NK cells regarding CD94 expression between ex-smoker COPD and HNS (13). In contrast, Tang et al. found increased inhibitory receptor $\mathrm{CD}_{158 \mathrm{a}^{+}}$and $\mathrm{CD} 158 \mathrm{~b}^{+}$PB NK cells in COPD patients, which 
were negatively correlated with pulmonary function, indicating that NK cell inhibitory receptors may contribute to COPD progression (69). There is still no consensus on reliable observation about inhibitory receptors of NK cells concerning COPD. which may due to different locations of NK cells, receptor types, smoking status, disease severity. Thus, in-depth research is urgently need.

\section{Altered Effector Functions of NK Cells}

NK cells may perform effector functions through producing perforin, granzyme indirectly and killing target cells through cytotoxicity directly (12). Urbanowicz et al. found that the CD56 ${ }^{\text {bright }} \mathrm{CD} 16^{-} \mathrm{NK}$ cells subpopulation in induced sputum produced significantly more perforin and granzyme B in COPD patients compared with HNS and smokers. However, they observed no difference in the percentages of CD56 ${ }^{\text {bright }} \mathrm{CD} 16$ and $\mathrm{CD} 56^{\mathrm{dim}} \mathrm{CD} 16^{+} \mathrm{NK}$ cells producing only perforin and no granzyme B (74). One study by Hodge et al., who reported that there were a higher percentage of $\mathrm{PB}$ and BALF NK cell expressing granzyme B in COPD patients compared with HNS (13). Similarly, there were significantly higher percentage of $\mathrm{PB}$ $\mathrm{CD} 56{ }^{\mathrm{dim}} \mathrm{CD} 16{ }^{+}$subset expressing only perforin and no granzyme $\mathrm{B}$ in COPD patients compared with the two other group (78). In contrast, Tang et al. found decreased IFN- $\gamma$ production in PB NK cells of COPD patients compared with HNS (69) Additionally, the percentage of $\mathrm{PB} \mathrm{NK}$ cells expressing both perforin and granzyme B decreased obviously in COPD patients in relative to smokers and HNS, while not the $\mathrm{CD} 56^{\text {bright }} \mathrm{CD} 16^{-}$subset. However, no difference between the percentage of $\mathrm{PB}$ $\mathrm{CD} 56^{\text {bright }} \mathrm{CD} 16^{-}$or $\mathrm{CD} 56^{\mathrm{dim}} \mathrm{CD} 16^{+}$subsets expressing only granzyme $B$ and no perforin was observed. Similarly, the proportion of $\mathrm{CD} 56^{\text {bright }} \mathrm{CD} 16^{-} \mathrm{PB} \mathrm{NK}$ expressing only perforin and no granzyme B showed no differences between the three groups (78). Additionally, no changes were observed regarding Granzyme A and perforin expression in PB NK cells between COPD patients and HNS (13). Even though these results involving cytokines production are of great promising, they are preliminary and definitely need further investigation.

In addition to cytokine production, it is worth mentioning that cytotoxicity, another mechanism through which NK cells perform direct killing effect, play a vital role in COPD pathogenesis. In one article, Urbanowicz et al. found that the cytotoxicity of PB NK cells from COPD patients was lower than those from smokers and HNS, and similarly decreased cytotoxicity was observed in smokers compared with HNS. Particularly, they observed a positive correlation between the cytotoxicity of PB NK cells and the lung function (78). The decreased cytotoxicity of PB NK cells in COPD patients was also confirmed by Prieto and his colleagues, and this decline could be rescued by Glycophosphopeptical treatment (70). In line with this, Hughes et al. found that heavy smokers showed decreased PB NK cell cytotoxicity, but normal ADCC (71). Similarly, Phillips et al. also reported that $\mathrm{PB}$ NK cells from heavy smokers displayed declined cytotoxicity, which was normal in mild smokers (72). However, several studies observed contrary findings. One study by Hodge et al., found that BALF NK cells showed elevated cytotoxicity in COPD patients compared with HNS (13). Similarly, a higher cytotoxicity of lung NK cells was also observed in COPD patients compared with smokers, and these NK cells induced severer injury of the lung epithelium. This article indicated that increased cytotoxicity in COPD was driven by lung NKs, not lung epithelial cells. The study also demonstrated that dendritic cells (DCs) from COPD patients could significantly enhance NK cell cytotoxicity through IL15Rotrans-presentation, suggesting that blocking IL-15 may protect lung epithelial cells from injury (14). Another study reported a positive correlation between enhanced stress-induced NK cell cytotoxicity and COPD severity, suggesting the contribution of heightened lung NK cell cytotoxicity in emphysema progression (73). All these observations implies that the intervention of cytotoxicity, cytokine release may be potential targets of COPD treatment.

\section{Adhesion Molecules of NK Cells}

Richard et al. found that CXCR3 and very late antigen-4(VLA-4) expression in $\mathrm{CD} 56^{\text {bright }} \mathrm{CD} 16^{-}$and $\mathrm{CD} 56^{\mathrm{dim}} \mathrm{CD} 16^{+} \mathrm{NK}$ cells elevated significantly in COPD patients compared with smokers (74). Another study by Chen et al., observed that intracellular expression of formyl peptide receptor (FPR3) in PB NK cells was markedly decreased in COPD patients compared with HNS. Particularly, this FPR3 expression showed a positive correlation with pre-bronchodilator FEV1/FVC ratio and predicted FEV1 percentage. FPR3 expression in COPD patients showed obvious elevation after 1-year treatment, suggesting the promising role of NK cell FPR3 in COPD therapy (67). Thus, searching for potential responsible molecule may be promising in the therapy of COPD.

\section{NK Cells in AECOPD of Human}

Exacerbations are vital events in the management of COPD for their negative effect on health status, hospitalization and readmission rates as well as disease progression, which are primarily triggered by viral and/or bacterial infections (5). In one study, higher levels of $\mathrm{PB} \mathrm{NKG}_{2} \mathrm{C}^{+} \mathrm{NK}$ cells were closely associated with the number of exacerbations, implying a potential role in predicting COPD exacerbations (68). Another study reported that NK cells from COPD patients were not responsive to $\mathrm{S}$. pneumoniae, suggesting function defect of $\mathrm{NK}$ cells in COPD patients (65). Up till now, the role of NK cells in AECOPD remains under-appreciated, and in-depth investigation holds promise for better understanding the immune mechanisms underlying infection-related acute exacerbation and deterioration of the disease.

\section{Concluding Remarks}

As innate immune cells, NK cells are considered to be the first line of defense mechanism for the human body against infections and tumor. Available data demonstrate that NK cells probably play a pivotal role in COPD and its exacerbations. Though advances have been made in revealing the potential involvement of NK cells in COPD, there still remain discrepancy involving NK cells frequency, activating and inhibitory receptors, effector functions, which may be attributable to different compartment of NK cells, 
different stages of disease in human and different dose of CS exposure in mouse model of COPD. Thus, further studies are urgently needed to elucidate the mechanisms of NK cells in the pathogenesis, endotypes and acute exacerbations of COPD. Particularly, the investigators should pay more attention to cross talks between adaptive immune cell and NK cells, NK cells and epithelial cells, which may shed light on the mechanisms of lung damage (emphysema), a hallmark of COPD. Also, investigators should put emphasis on researches involving inhibitory, activating receptors and chemokine receptor in NK cells and its ligand in epithelial cells, thus develop more potent agonists/antagonists, which may pave the way to facilitate the translation of such a promising strategy into clinical use for therapy of COPD and AECOPD.

\section{REFERENCES}

1. Soriano JB, Abajobir AA, Abate KH, Abera SF, Agrawal A, Ahmed MB, et al. Global, Regional, and National Deaths, Prevalence, Disability-Adjusted Life Years, and Years Lived With Disability for Chronic Obstructive Pulmonary Disease and Asthma, 1990-2015: A Systematic Analysis for the Global Burden of Disease Study 2015. Lancet Respir Med (2017) 5(9):691-706. doi: 10.1016/ s2213-2600(17)30293-x

2. Wang H, Naghavi M, Allen C, Barber RM, Bhutta ZA, Carter A, et al. Global, Regional, and National Life Expectancy, All-Cause Mortality, and CauseSpecific Mortality for 249 Causes of Death, 1980-2015: A Systematic Analysis for the Global Burden of Disease Study 2015. Lancet (2016) 388(10053):1459544. doi: 10.1016/s0140-6736(16)31012-1

3. Wang C, Xu J, Yang L, Xu Y, Zhang X, Bai C, et al. Prevalence and Risk Factors of Chronic Obstructive Pulmonary Disease in China (the China Pulmonary Health [CPH] Study): A National Cross-Sectional Study. Lancet (2018) 391(10131):1706-17. doi: 10.1016/s0140-6736(18)30841-9

4. Bhatt SP, Kim YI, Harrington KF, Hokanson JE, Lutz SM, Cho MH, et al. Smoking Duration Alone Provides Stronger Risk Estimates of Chronic Obstructive Pulmonary Disease Than Pack-Years. Thorax (2018) 73 (5):414-21. doi: 10.1136/thoraxjnl-2017-210722

5. Vogelmeier CF, Criner GJ, Martinez FJ, Anzueto A, Barnes PJ, Bourbeau J, et al. Global Strategy for the Diagnosis, Management, and Prevention of Chronic Obstructive Lung Disease 2017 Report. GOLD Executive Summary Am J Respir Crit Care Med (2017) 195(5):557-82. doi: 10.1164/rccm.2017010218PP

6. White AJ, Gompertz S, Stockley RA. Chronic Obstructive Pulmonary Disease . 6: The Aetiology of Exacerbations of Chronic Obstructive Pulmonary Disease. Thorax (2003) 58(1):73-80. doi: 10.1136/thorax.58.1.73

7. Calderazzo MA, Trujillo-Torralbo M-B, Finney LJ, Singanayagam A, Bakhsoliani E, Padmanaban V, et al. Inflammation and Infections in Unreported Chronic Obstructive Pulmonary Disease Exacerbations. Int J Chronic Obstructive Pulmonary Dis (2019) 14:823-32. doi: 10.2147/ COPD.S191946

8. Barnes PJ. Inflammatory Mechanisms in Patients With Chronic Obstructive Pulmonary Disease. J Allergy Clin Immunol (2016) 138(1):16-27. doi: 10.1016/j.jaci.2016.05.011

9. Hou J, Sun Y. Role of Regulatory T Cells in Disturbed Immune Homeostasis in Patients With Chronic Obstructive Pulmonary Disease. Front Immunol (2020) 11:723. doi: 10.3389/fimmu.2020.00723

10. Vivier E, Tomasello E, Baratin M, Walzer T, Ugolini S. Functions of Natural Killer Cells. Nat Immunol (2008) 9(5):503-10. doi: 10.1038/ni1582

11. Cong J, Wei H. Natural Killer Cells in the Lungs. Front Immunol (2019) 10:1416. doi: 10.3389/fimmu.2019.01416

12. Hervier B, Russick J, Cremer I, Vieillard V. Nk Cells in the Human Lungs. Front Immunol (2019) 10:1263. doi: 10.3389/fimmu.2019.01263

13. Hodge G, Mukaro V, Holmes M, Reynolds PN, Hodge S. Enhanced Cytotoxic Function of Natural Killer and Natural Killer T-like Cells Associated With

\section{AUTHOR CONTRIBUTIONS}

YR analyzed the data and prepared the manuscript. YS contributed to the scientific expertise and manuscript preparation. YL, JX, and YP participated in the preparation of the manuscript. All authors contributed to the article and approved the submitted version.

\section{FUNDING}

This work was supported by the National Natural Science Foundation of China $(81770040,81970041)$ and Natural Science Foundation of Beijing Municipality (7192224).

Decreased CD94 (Kp43) in the Chronic Obstructive Pulmonary Disease Airway. Respirology (2013) 18(2):369-76. doi: 10.1111/j.1440-1843.2012.02287.x

14. Finch DK, Stolberg VR, Ferguson J, Alikaj H, Kady MR, Richmond BW, et al. Lung Dendritic Cells Drive Natural Killer Cytotoxicity in Chronic Obstructive Pulmonary Disease Via IL-15R $\alpha$. Am J Respir Crit Care Med (2018) 198 (9):1140-50. doi: 10.1164/rccm.201712-2513OC

15. Scoville SD, Freud AG, Caligiuri MA. Modeling Human Natural Killer Cell Development in the Era of Innate Lymphoid Cells. Front Immunol (2017) 8:360. doi: 10.3389/fimmu.2017.00360

16. Yu J, Freud AG, Caligiuri MA. Location and Cellular Stages of Natural Killer Cell Development. Trends Immunol (2013) 34(12):573-82. doi: 10.1016/ j.it.2013.07.005

17. Akashi K, Traver D, Kondo M, Weissman IL. Lymphoid Development From Hematopoietic Stem Cells. Int J Hematol (1999) 69(4):217-26.

18. Higuchi Y, Zeng H, Ogawa M. CD38 Expression by Hematopoietic Stem Cells of Newborn and Juvenile Mice. Leukemia (2003) 17(1):171-4. doi: 10.1038/ sj.leu. 2402785

19. Rabinowich H, Pricop L, Herberman RB, Whiteside TL. Expression and Function of CD7 Molecule on Human Natural Killer Cells. J Immunol (Baltimore Md 1950) (1994) 152(2):517-26.

20. Luetke-Eversloh M, Killig M, Romagnani C. Signatures of Human NK Cell Development and Terminal Differentiation. Front Immunol (2013) 4:499. doi: 10.3389/fimmu.2013.00499

21. Renoux VM, Zriwil A, Peitzsch C, Michaëlsson J, Friberg D, Soneji S, et al. Identification of a Human Natural Killer Cell Lineage-Restricted Progenitor in Fetal and Adult Tissues. Immunity (2015) 43(2):394-407. doi: 10.1016/ j.immuni.2015.07.011

22. Mace EM, Hsu AP, Monaco-Shawver L, Makedonas G, Rosen JB, Dropulic L, et al. Mutations in GATA2 Cause Human NK Cell Deficiency With Specific Loss of the CD56(bright) Subset. Blood (2013) 121(14):2669-77. doi: 10.1182/ blood-2012-09-453969

23. Freud AG, Keller KA, Scoville SD, Mundy-Bosse BL, Cheng S, Youssef Y, et al. Nkp80 Defines a Critical Step During Human Natural Killer Cell Development. Cell Rep (2016) 16(2):379-91. doi: 10.1016/j.celrep.2016.05.095

24. Vitale M, Falco M, Castriconi R, Parolini S, Zambello R, Semenzato G, et al. Identification of NKp80, a Novel Triggering Molecule Expressed by Human NK Cells. Eur J Immunol (2001) 31(1):233-42. doi: 10.1002/1521-4141 (200101)31:1<233::aid-immu233>3.0.co;2-4

25. Farag SS, Caligiuri MA. Human Natural Killer Cell Development and Biology. Blood Rev (2006) 20(3):123-37. doi: 10.1016/j.blre.2005.10.001

26. Abel AM, Yang C, Thakar MS, Malarkannan S. Natural Killer Cells: Development, Maturation, and Clinical Utilization. Front Immunol (2018) 9:1869. doi: 10.3389/fimmu.2018.01869

27. Robinson BW, Pinkston P, Crystal RG. Natural Killer Cells are Present in the Normal Human Lung But are Functionally Impotent. J Clin Invest (1984) 74 (3):942-50. doi: 10.1172/jci111513

28. Marquardt N, Kekalainen E, Chen P, Kvedaraite E, Wilson JN, Ivarsson MA, et al. Human Lung Natural Killer Cells are Predominantly Comprised of 
Highly Differentiated Hypofunctional CD69(-)CD56(dim) Cells. J Allergy Clin Immunol (2017) 139(4):1321-30.e4. doi: 10.1016/j.jaci.2016.07.043

29. Cooper GE, Ostridge K, Khakoo SI, Wilkinson TMA, Staples KJ. Human $\mathrm{CD} 49 \mathrm{a}(+)$ Lung Natural Killer Cell Cytotoxicity in Response to Influenza A Virus. Front Immunol (2018) 9:1671. doi: 10.3389/fimmu.2018.01671

30. Castriconi R, Carrega P, Dondero A, Bellora F, Casu B, Regis S, et al. Molecular Mechanisms Directing Migration and Retention of Natural Killer Cells in Human Tissues. Front Immunol (2018) 9:2324. doi: 10.3389/fimmu.2018.02324

31. Dogra P, Rancan C, Ma W, Toth M, Senda T, Carpenter DJ, et al. Tissue Determinants of Human Nk Cell Development, Function, and Residence. Cell (2020) 180(4):749-63.e13. doi: 10.1016/j.cell.2020.01.022

32. Freud AG, Mundy-Bosse BL, Yu J, Caligiuri MA. The Broad Spectrum of Human Natural Killer Cell Diversity. Immunity (2017) 47(5):820-33. doi: 10.1016/j.immuni.2017.10.008

33. Björkström NK, Ljunggren HG, Michaëlsson J. Emerging Insights Into Natural Killer Cells in Human Peripheral Tissues. Nat Rev Immunol (2016) 16(5):310-20. doi: 10.1038/nri.2016.34

34. Melsen JE, Lugthart G, Lankester AC, Schilham MW. Human Circulating and Tissue-Resident CD56(Bright) Natural Killer Cell Populations. Front Immunol (2016) 7:262. doi: 10.3389/fimmu.2016.00262

35. Lugthart G, Melsen JE, Vervat C, van Ostaijen-Ten Dam MM, Corver WE, Roelen DL, et al. Human Lymphoid Tissues Harbor a Distinct Cd69+Cxcr6+ NK Cell Population. J Immunol (2016) 197(1):78-84. doi: 10.4049/ jimmunol.1502603

36. Bjorkstrom NK, Riese P, Heuts F, Andersson S, Fauriat C, Ivarsson MA, et al. Expression Patterns of NKG2A, KIR, and CD57 Define a Process of CD56dim NK-Cell Differentiation Uncoupled From NK-cell Education. Blood (2010) 116(19):3853-64. doi: 10.1182/blood-2010-04-281675

37. Del Zotto G, Antonini F, Pesce S, Moretta F, Moretta L, Marcenaro E. Comprehensive Phenotyping of Human Pb NK Cells by Flow Cytometry. Cytometry A (2020) 97(9):891-9. doi: 10.1002/cyto.a.24001

38. Sun C, Sun H, Zhang C, Tian Z. NK Cell Receptor Imbalance and NK Cell Dysfunction in HBV Infection and Hepatocellular Carcinoma. Cell Mol Immunol (2015) 12(3):292-302. doi: 10.1038/cmi.2014.91

39. Montaldo E, Del Zotto G, Della Chiesa M, Mingari MC, Moretta A, De Maria A, et al. Human NK Cell Receptors/Markers: A Tool to Analyze NK Cell Development, Subsets and Function. Cytometry A (2013) 83(8):702-13. doi: $10.1002 /$ cyto.a.22302

40. Diefenbach A, Raulet DH. Innate Immune Recognition by Stimulatory Immunoreceptors. Curr Opin Immunol (2003) 15(1):37-44. doi: 10.1016/ s0952-7915(02)00007-9

41. Lanier LL. NK Cell Recognition. Annu Rev Immunol (2005) 23:225-74. doi: 10.1146/annurev.immunol.23.021704.115526

42. Raulet DH, Vance RE. Self-Tolerance of Natural Killer Cells. Nat Rev Immunol (2006) 6(7):520-31. doi: 10.1038/nri1863

43. Wang J, Li F, Zheng M, Sun R, Wei H, Tian Z. Lung Natural Killer Cells in Mice: Phenotype and Response to Respiratory Infection. Immunology (2012) 137(1):37-47. doi: 10.1111/j.1365-2567.2012.03607.x

44. Stein-Streilein J, Bennett M, Mann D, Kumar V. Natural Killer Cells in Mouse Lung: Surface Phenotype, Target Preference, and Response to Local Influenza Virus Infection. J Immunol (1983) 131(6):2699-704.

45. Hammer Q, Rückert T, Romagnani C. Natural Killer Cell Specificity for Viral Infections. Nat Immunol (2018) 19(8):800-8. doi: 10.1038/s41590-018-0163-6

46. Orange JS. Human Natural Killer Cell Deficiencies and Susceptibility to Infection. Microbes Infect (2002) 4(15):1545-58. doi: 10.1016/s1286-4579 (02)00038-2

47. Orange JS, Brodeur SR, Jain A, Bonilla FA, Schneider LC, Kretschmer R, et al. Deficient Natural Killer Cell Cytotoxicity in Patients With IKK-gamma/ NEMO Mutations. J Clin Invest (2002) 109(11):1501-9. doi: 10.1172/jci14858

48. Feng CG, Kaviratne M, Rothfuchs AG, Cheever A, Hieny S, Young HA, et al. NK Cell-Derived IFN-gamma Differentially Regulates Innate Resistance and Neutrophil Response in T Cell-Deficient Hosts Infected With Mycobacterium Tuberculosis. J Immunol (2006) 177(10):7086-93. doi: 10.4049/ jimmunol.177.10.7086

49. Liu CH, Liu H, Ge B. Innate Immunity in Tuberculosis: Host Defense vs Pathogen Evasion. Cell Mol Immunol (2017) 14(12):963-75. doi: 10.1038/ cmi.2017.88
50. Gerosa F, Baldani-Guerra B, Nisii C, Marchesini V, Carra G, Trinchieri G Reciprocal Activating Interaction Between Natural Killer Cells and Dendritic Cells. J Exp Med (2002) 195(3):327-33. doi: 10.1084/jem.20010938

51. Feinberg J, Fieschi C, Doffinger R, Feinberg M, Leclerc T, Boisson-Dupuis S, et al. Bacillus Calmette Guerin Triggers the IL-12/IFN-gamma Axis by an IRAK-4- and NEMO-dependent, non-Cognate Interaction Between Monocytes, NK, and T Lymphocytes. Eur J Immunol (2004) 34(11):327684. doi: 10.1002/eji.200425221

52. Xu X, Weiss ID, Zhang HH, Singh SP, Wynn TA, Wilson MS, et al. Conventional NK Cells can Produce IL-22 and Promote Host Defense in Klebsiella Pneumoniae Pneumonia. J Immunol (2014) 192(4):1778-86. doi: 10.4049/jimmunol.1300039

53. Ivin M, Dumigan A, de Vasconcelos FN, Ebner F, Borroni M, Kavirayani A, et al. Natural Killer Cell-Intrinsic Type I IFN Signaling Controls Klebsiella Pneumoniae Growth During Lung Infection. PloS Pathog (2017) 13(11): e1006696. doi: 10.1371/journal.ppat.1006696

54. Yoshihara R, Shiozawa S, Fujita T, Chihara K. Gamma Interferon is Produced by Human Natural Killer Cells But Not T Cells During Staphylococcus Aureus Stimulation. Infect Immun (1993) 61(8):3117-22. doi: 10.1128/iai.61.8.31173122.1993

55. Small CL, McCormick S, Gill N, Kugathasan K, Santosuosso M, Donaldson N, et al. NK Cells Play a Critical Protective Role in Host Defense Against Acute Extracellular Staphylococcus Aureus Bacterial Infection in the Lung. J Immunol (2008) 180(8):5558-68. doi: 10.4049/jimmunol.180.8.5558

56. Miyazaki S, Ishikawa F, Shimizu K, Ubagai T, Edelstein PH, Yamaguchi K. Gr1high Polymorphonuclear Leukocytes and NK Cells Act Via IL-15 to Clear Intracellular Haemophilus Influenzae in Experimental Murine Peritonitis and Pneumonia. J Immunol (2007) 179(8):5407-14. doi: 10.4049/ jimmunol.179.8.5407

57. Motz GT, Eppert BL, Wortham BW, Amos-Kroohs RM, Flury JL, Wesselkamper SC, et al. Chronic Cigarette Smoke Exposure Primes NK Cell Activation in a Mouse Model of Chronic Obstructive Pulmonary Disease. J Immunol (2010) 184(8):4460-9. doi: 10.4049/jimmunol.0903654

58. Wortham BW, Eppert BL, Motz GT, Flury JL, Orozco-Levi M, Hoebe K, et al. NKG2D Mediates NK Cell Hyperresponsiveness and Influenza-Induced Pathologies in a Mouse Model of Chronic Obstructive Pulmonary Disease. J Immunol (2012) 188(9):4468-75. doi: 10.4049/jimmunol.1102643

59. Bozinovski S, Seow HJ, Chan SP, Anthony D, McQualter J, Hansen M, et al. Innate Cellular Sources of interleukin-17A Regulate Macrophage Accumulation in Cigarette- Smoke-Induced Lung Inflammation in Mice. Clin Sci (Lond) (2015) 129(9):785-96. doi: 10.1042/cs20140703

60. Stolberg VR, Martin B, Mancuso P, Olszewski MA, Freeman CM, Curtis JL, et al. Role of CC Chemokine Receptor 4 in Natural Killer Cell Activation During Acute Cigarette Smoke Exposure. Am J Pathol (2014) 184(2):454-63. doi: 10.1016/j.ajpath.2013.10.017

61. Wortham BW, Eppert BL, Flury JL, Morgado Garcia S, Borchers MT. TLR and NKG2D Signaling Pathways Mediate CS-induced Pulmonary Pathologies. PloS One (2013) 8(10):e78735. doi: 10.1371/journal.pone.0078735

62. Borchers MT, Wesselkamper SC, Curull V, Ramirez-Sarmiento A, SánchezFont A, Garcia-Aymerich J, et al. Sustained CTL Activation by Murine Pulmonary Epithelial Cells Promotes the Development of COPD-like Disease. J Clin Invest (2009) 119(3):636-49. doi: 10.1172/JCI34462

63. Marin A, Monso E, Garcia-Nunez M, Sauleda J, Noguera A, Pons J, et al. Variability and Effects of Bronchial Colonisation in Patients With Moderate COPD. Eur Respir J (2010) 35(2):295-302. doi: 10.1183/09031936.00126808

64. Mian MF, Pek EA, Mossman KL, Stämpfli MR, Ashkar AA. Exposure to Cigarette Smoke Suppresses IL-15 Generation and its Regulatory NK Cell Functions in Poly I:C-augmented Human Pbmcs. Mol Immunol (2009) 46 (15):3108-16. doi: 10.1016/j.molimm.2009.06.009

65. Pichavant M, Sharan R, Le Rouzic O, Olivier C, Hennegrave F, Rémy G, et al. Il-22 Defect During Streptococcus Pneumoniae Infection Triggers Exacerbation of Chronic Obstructive Pulmonary Disease. EBioMedicine (2015) 2(11):1686-96. doi: 10.1016/j.ebiom.2015.09.040

66. Wang J, Urbanowicz RA, Tighe PJ, Todd I, Corne JM, Fairclough LC. Differential Activation of Killer Cells in the Circulation and the Lung: A Study of Current Smoking Status and Chronic Obstructive Pulmonary Disease (COPD). PloS One (2013) 8(3):e58556-6. doi: 10.1371/journal.pone.0058556 
67. Chen YC, Lin MC, Lee CH, Liu SF, Wang CC, Fang WF, et al. Defective Formyl Peptide Receptor 2/3 and Annexin A1 Expressions Associated With M2a Polarization of Blood Immune Cells in Patients With Chronic Obstructive Pulmonary Disease. J Transl Med (2018) 16(1):69. doi: 10.1186/ s12967-018-1435-5

68. Pascual-Guardia S, Ataya M, Ramírez-Martínez I, Yélamos J, Chalela R, Bellido S, et al. Adaptive NKG2C+ Natural Killer Cells are Related to Exacerbations and Nutritional Abnormalities in COPD Patients. Respir Res (2020) 21(1):63. doi: 10.1186/s12931-020-1323-4

69. Tang Y, Li X, Wang M, Zou Q, Zhao S, Sun B, et al. Increased Numbers of NK Cells, NKT-like Cells, and NK Inhibitory Receptors in Peripheral Blood of Patients With Chronic Obstructive Pulmonary Disease. Clin Dev Immunol (2013) 2013:721782-2. doi: 10.1155/2013/721782

70. Prieto A, Reyes E, Bernstein ED, Martinez B, Monserrat J, Izquierdo JL, et al. Defective Natural Killer and Phagocytic Activities in Chronic Obstructive Pulmonary Disease are Restored by Glycophosphopeptical (Inmunoferón). Am J Respir Crit Care Med (2001) 163(7):1578-83. doi: 10.1164/ajrccm. 163.7.2002015

71. Hughes DA, Haslam PL, Townsend PJ, Turner-Warwick M. Numerical and Functional Alterations in Circulatory Lymphocytes in Cigarette Smokers. Clin Exp Immunol (1985) 61(2):459-66.

72. Phillips B, Marshall ME, Brown S, Thompson JS. Effect of Smoking on Human Natural Killer Cell Activity. Cancer (1985) 56(12):2789-92. doi: 10.1002/10970142(19851215)56:12<2789::aid-cncr2820561213>3.0.co;2-2

73. Freeman CM, Stolberg VR, Crudgington S, Martinez FJ, Han MK, Chensue SW, et al. Human CD56+ Cytotoxic Lung Lymphocytes Kill Autologous Lung Cells in Chronic Obstructive Pulmonary Disease. PloS One (2014) 9(7): e103840. doi: 10.1371/journal.pone.0103840
74. Urbanowicz RA, Lamb JR, Todd I, Corne JM, Fairclough LC. Enhanced Effector Function of Cytotoxic Cells in the Induced Sputum of COPD Patients. Respir Res (2010) 11(1):76. doi: 10.1186/1465-9921-11-76

75. Olloquequi J, Montes JF, Prats A, Rodríguez E, Montero MA, García-Valero J, et al. Significant Increase of CD57+ Cells in Pulmonary Lymphoid Follicles of COPD Patients. Eur Respir J (2011) 37(2):289-98. doi: 10.1183/09031936. 00201509

76. Tollerud DJ, Clark JW, Brown LM, Neuland CY, Mann DL, Pankiw-Trost LK, et al. Association of Cigarette Smoking With Decreased Numbers of Circulating Natural Killer Cells. Am Rev Respir Dis (1989) 139(1):194-8. doi: 10.1164/ajrccm/139.1.194

77. Moszczynski P, Rutowski J, Slowinski S. The Effect of Cigarettes Smoking on the Blood Counts of T and NK Cells in Subjects With Occupational Exposure to Organic Solvents. Cent Eur J Public Health (1996) 4(3):164-8.

78. Urbanowicz RA, Lamb JR, Todd I, Corne JM, Fairclough LC. Altered Effector Function of Peripheral Cytotoxic Cells in COPD. Respir Res (2009) 10(1):53-3. doi: 10.1186/1465-9921-10-53

Conflict of Interest: The authors declare that the research was conducted in the absence of any commercial or financial relationships that could be construed as a potential conflict of interest.

Copyright (C) 2021 Rao, Le, Xiong, Pei and Sun. This is an open-access article distributed under the terms of the Creative Commons Attribution License (CC BY). The use, distribution or reproduction in other forums is permitted, provided the original author(s) and the copyright owner(s) are credited and that the original publication in this journal is cited, in accordance with accepted academic practice. No use, distribution or reproduction is permitted which does not comply with these terms. 